\title{
Apparent digestibility and nutritional composition of Leucaena leucocephala (Lam) leaf meal incorporated in the diets of Black Australorp and Potchefstroom Koekoek chicken breeds
}

\author{
Marupine Windy Thamaga ${ }^{1,2}$ (D) Hilda Kwena Mokoboki ${ }^{2,3} \cdot$ Nthabiseng Amenda Sebola $^{4}$. \\ Khuliso Emmanuel Ravhuhali ${ }^{2,3}$
}

Received: 27 January 2021 / Accepted: 10 September 2021 / Published online: 20 September 2021

(C) The Author(s) 2021

\begin{abstract}
The objective of the study was to determine the apparent digestibility and nutrient composition of Leucaena leucocephala leaf meal (LLM) inclusion in Black Australorp and Potchefstroom Koekoek diets. Tender and mature leaves were separately harvested from 10 individual trees and stored separately for chemical analyses. The leaves were air-dried in a well-ventilated laboratory to constant weight and milled to pass through a 1-mm sieve. A mixture of tender and mature leaves was also collected to produce a bulk leaf meal. The four iso-nitrogenous dietary treatments were 0 (control), 2.5, 5.0 and 7.5\% of LLM, respectively. The apparent digestibility of two chicken breeds was also evaluated. The dry matter (DM), neutral detergent fibre (NDF), ether extract (EE), cellulose and hemicellulose of the samples did not differ between tender and mature leaves. Tender leaves had higher $(P<0.05)$ calcium, potassium, magnesium and sodium concentration than mature leaves. Crude protein and mimosine content were significantly $(P<0.05)$ higher in tender than in mature leaves. The inclusion levels of $L$. leucocephala leaf meal affect $(P<0.05)$ acid detergent fibre $(\mathrm{ADF})$, neutral detergent fibre (NDF) and crude protein $(\mathrm{CP})$ digestibility. Crude protein digestibility decreases as the inclusion levels of $L$. leucocephala increase. Both tender and mature L. leисосеphala leaves have a potential nutritional value that can be used in feedstuff and can be used as a protein supplement for Black Australorp and Potchefstroom Koekoek chicken breeds.
\end{abstract}

Keywords Black Australorp $\cdot$ Mature leaves $\cdot$ Nutrient intake $\cdot$ Potchefstroom Koekoek $\cdot$ Tender leaves

Marupine Windy Thamaga

mwthamaga@gmail.com

1 Department of Agriculture, Rural Development, Land and Environmental Affairs, Private Bag x3001, Mbibane, Dr JS Moroka Municipality, Mpumalanga Province, South Africa

2 Department of Animal Science, School of Agricultural Sciences, Faculty of Natural and Agricultural Sciences, North West University, Mafikeng Campus, Mmabatho 2735, South Africa

3 Food Security and Safety Niche Area, Faculty of Natural and Agricultural Sciences, North West University, Mafikeng Campus, Mmabatho 2735, South Africa

4 School of Agriculture and Life Science, Department of Agriculture and Animal Health, University of South Africa, Florida Science Campus, Roodepoort 1710, South Africa

\section{Introduction}

Poultry production plays a vital role in the improvement of the income and food security of the communal poultry producers (Sonaiya 2003). Chickens are a source of protein to the ever-increasing population in developing countries (Dyubele et al. 2010). Farmers especially in rural areas prefer communal indigenous chickens because they are not capital intensive (Muchadeyi et al. 2007). Communal chicken production refers to birds kept under extensive system, scavenging in the free range, have no identified description, multi-purpose and unimproved (Mngonyama 2012). The most common South African breeds kept in communal areas include Potchefstroom Koekoek, Ovambo, LebowaVenda and Naked-Neck. The other European breeds that are kept for free range systems (extensive) are New Hampshire, Rhode Island Red and Black Australorp (Mngonyama 2012).

The Potchefstroom Koekoek was bred during the 1950s at the former Potchefstroom Agricultural Research Institute 
from cross between the White Leghorn, Black Australorp and Bared Plymouth Rock and is recognized as a locally developed breed (FAO 2014). It is categorized as a heavy breed whereas characterized by relative high egg production and adaptability for household production. It is a dualpurpose breed that lays brown-shelled eggs with an average weight of $55.7 \mathrm{~g}$ (Ramsey et al. 2001). The meat of the Potchefstroom Koekoek is popular amongst household communities and is favoured like the commercial broiler hybrids (Grobbelaar 2008). The Potchefstroom Koekoek colour form is a sex-related gene that is beneficial for colour sexing in cross-breeding for egg producing types of hens used in medium input production systems. In African countries, the breed is well known for their egg, mothering ability and meat production (Grobbelaar 2008). Tadelle and Fasil (2016) reported that the average body weight of Potchefstroom males is around $3-4 \mathrm{~kg}$ and of females is $2.1 \mathrm{~kg}$. The Potchefstroom Koekoek reaches sexual maturity at 18.5 days of age (Grobbelaar et al. 2010).

The most commonly imported chicken breed used in South Africa is Black Australorp. The Australorp chicken was developed as a result of improving the English Orpington in Australia. They were recognized as Black Utility Orpington. The breed was acknowledged as Standard Perfection in 1929. Australorp chickens are black in colour. Males have an average body weight of $3.85 \mathrm{~kg}$ and females $2.94 \mathrm{~kg}$ (Fourie and Grobbelaar 2003). The breed is large, soft-feathered chicken with glossy black feathers and a lustrous green sheen. The Black Australorp chicken is hardy, docile, good layer, reach early maturity and also a good meat breed. The body weight of large Australorp roosters is between 3.9 and $4.7 \mathrm{~kg}$, while hens weigh between 3.7 and $4.5 \mathrm{~kg}$. The rooster of a bantam has a body weight between 1.8 and $2.3 \mathrm{~kg}$, while hens weigh between 1.7 and $2.2 \mathrm{~kg}$ (small-farm-permicultu re-and-sustainability-living.com 2012).

Okitoi et al. (2006) and Mbajiorgu et al. (2011) reported that the productivity of indigenous chickens is very low and mortality is high, emphasizing that appropriate genetic, nutritional and management interventions are required to appreciate their ultimate production potential. Nutritional strategies must be considered to promote and improve the productivity of indigenous chickens which will effectively contribute to poverty alleviation. Several studies revealed that leaves of Alchornea cordifolia, Chromolaena odorata, Leucaena leucocephala and Moringa oleifera are important feed resources which are relatively rich in crude protein (25-44\%), essential amino acids, minerals, carotenoids and vitamins (Tendonkeng et al. 2008; Olugbemi et al. 2010; Houndonougbo et al. 2012). Amongst those resources, Leucaena can play an important role when included in the diets of egg-laying hens (Safwat et al. 2014). L. leucocephala leaves contain $23.3 \% \mathrm{DM}$ of crude protein, $11.4 \% \mathrm{DM}$ ash, $2573.8 \mathrm{kcal} / \mathrm{kg}$ DM metabolizable energy, $0.38 \%$ calcium,
2.9\% phosphorus and 1.6\% tannins (Onibi et al. 2008; Ayssiwede et al. 2011; Garcia et al. 1996). The plant age or stage of maturity also has substantial effect on the plant nutritional composition (Buxton 1996), whereby an increase in age of the plant has always been associated with an increase of cell wall. However, the limited information about the use and chemical composition of Leucaena for small-scale farmers might be a constraint to its use (Leketa et al. 2019). Although Leucaena has been reported to be highly palatable, the toxic mimosine content poses a challenge to its use in animal feeding (Sastry and Singh 2008). The purpose of this study was to determine the nutritional composition of air-dried L. leucocephala leaves and the digestibility of diets L. leucocephala meal (LLM) fed to Potchefstroom Koekoek and Black Australorp chicken breeds.

\section{Materials and methods}

\section{Harvesting site}

L. leucocephala leaves were harvested from Mpumalanga Province, South Africa. The harvesting site has a flat landscape with sandy to loamy soil type. The average mean temperature ranges from 12 in winter to $33{ }^{\circ} \mathrm{C}$ in summer times. The annual mean rainfall ranges between 400 and $800 \mathrm{~mm}$, with frost that normally occurs during winter season. L. leucocephala leaves were simultaneously harvested at two stages of maturity (tender and mature leaves) and stored separately.

\section{Bulk leaf samples}

L. leucocephala leaves were simultaneously harvested at two stages of maturity (tender and mature leaves) and stored separately. The leaves were harvested green, air-dried in a well-ventilated laboratory to constant weight and milled through a 1-mm sieve into a powder using a hammer mill before being subjected to chemical analyses. A 50:50 ratio of both tender and mature leaves of L. leucocephala leaf meal (LLM) bulk sample was used in the digestibility trial. The study was approved by university ethic committee (Ethics Number NWU 00242-18-A5).

\section{Diet formulation}

Four diets were formulated by supplementing a commercial broiler finisher diets with graded levels of $0,25,50$ and $75 \mathrm{~g} /$ $\mathrm{kg}$ of air-dried and milled L. leucocephala leaf meal (LLM). The chemical composition and formulation of LLM trial diets are stated in Table 1. The experimental diet formulation was done at a commercial feed manufacturing company, 
Table 1 Gross composition of Leucaena leucocephala leaf meal (LLM) diet-based experiment

\begin{tabular}{|c|c|c|c|c|}
\hline \multicolumn{5}{|l|}{ Dietary treatment $\%$} \\
\hline & Control & LLM2.5 & LLM5.0 & LLM7.5 \\
\hline \multicolumn{5}{|l|}{ Ingredients } \\
\hline Yellow maize, coarse & 60 & 60 & 60 & 60 \\
\hline Wheat bran & 12 & 12 & 10 & 10 \\
\hline L. leucocephala & 0 & 2.5 & 5 & 7.5 \\
\hline Soybean meal & 13 & 10.52 & 9.05 & 6.56 \\
\hline Sunflower oilcake & 9.7 & 9.75 & 10 & 10 \\
\hline Limestone powder, fine & 2 & 2 & 3.2 & 3.2 \\
\hline $\mathrm{MCP} / \mathrm{mono} \mathrm{Cal} \mathrm{KK}$ & 1 & 1 & 1 & 1 \\
\hline Salt, fine & 0.5 & 0.5 & 0.5 & 0.5 \\
\hline Bicarbonate & 0.17 & 0.24 & 0.24 & 0.24 \\
\hline Lysine & 1.22 & 1.04 & 0.71 & 0.7 \\
\hline Choline powder & 0.05 & 0.05 & 0.05 & 0.05 \\
\hline Methionine & 0.36 & 0.35 & 0.2 & 0.2 \\
\hline Premix $(\%)$ & 0.05 & 0.05 & 0.05 & 0.05 \\
\hline Total $(\%)$ & 100 & 100 & 100 & 100 \\
\hline \multicolumn{5}{|c|}{ Nutrient composition (\%) analysed } \\
\hline Dry matter $(\%)$ & 90.25 & 90.81 & 90.39 & 90.93 \\
\hline Ash $(\%)$ & 5.35 & 6.61 & 6.11 & 6.37 \\
\hline Crude protein $(\%)$ & 19.53 & 19.50 & 19.05 & 19.44 \\
\hline Fats $(\%)$ & 3.40 & 5.66 & 5.10 & 4.49 \\
\hline $\operatorname{ADF}(\%)$ & 10.25 & 10.57 & 10.92 & 11.17 \\
\hline $\operatorname{NDF}(\%)$ & 20.11 & 20.67 & 21.45 & 21.29 \\
\hline $\operatorname{ADL}(\%)$ & 2.74 & 3.59 & 3.77 & 4.58 \\
\hline Cellulose (\%) & 7.51 & 6.98 & 7.15 & 6.59 \\
\hline Hemicellulose $(\%)$ & 9.86 & 10.10 & 10.53 & 10.11 \\
\hline
\end{tabular}

$\%$, percentage; $A D F$, acid detergent fibre; $N D F$, neutral detergent fibre; $A D L$, acid detergent lignin; $L L M$ 2.5, 2.5 L. leucocephala leaf meal inclusion; LLM 5.0, 5.0 L. leucocephala leaf meal inclusion; LLM 7.5, 7.5 L. leucocephala leaf meal inclusion

Simple Grower (Pretoria). These experimental diets were formulated to be iso-nitrogenous.

\section{Chemical analyses}

The chemical analyses of each plant and bulk samples of leaf were carried out in the Animal Nutrition Laboratory at the North-West University Experimental Farm (Molelwane). Moisture and dry matter material contents were determined by weighing sample in crucible and drying in an oven over night at $105{ }^{\circ} \mathrm{C}$ to reach constant weight (AOAC 2005). The ash content was determined by ashing plant materials at $550{ }^{\circ} \mathrm{C}$ for $6 \mathrm{~h}$ in a muffle furnace. Total nitrogen content was analysed using the standard macroKjeldahl method (AOAC 2005), and it was converted to crude protein through multiplying percentage $\mathrm{N}$ content by 6.25. The neutral and acid detergent fibres (NDF and ADF) were assessed by refluxing $0.45 \mathrm{~g}$ samples with neutral detergent and acid detergent solutions, respectively, according to Van Soest et al. (1991). Heat stable ò-amylase was utilized for analyses of NDF with the exclusion of sodium sulphite. The chemical composition values were used to predict chemical estimates (DMDigest, TDN, DE, ME) of L. leucocephala leaves under different growth stages. The formula used to predict total digestible nutrients (TND) was $82.38-(0.7515 \times \mathrm{ADF})$ as described by Bath and Marble (1989). The formula for dry matter digestibility was DMDigest $\%=88.9-(0.779 \times \%$ ADF $)$. Dry matter digestibility values were used to estimate digestible energy (DE, $\mathrm{kcal} / \mathrm{kg}$ ) using the regression equation reported by Fonnesbeck et al. (1984), DE (Mcal $/ \mathrm{kg})=$ $0.27+0.0428$ (DMDigest\%). DE values were converted to ME using the formula reported by Khalil et al. (1986), ME $(\mathrm{Mcal} / \mathrm{kg})=0.821 \times \mathrm{DE}(\mathrm{Mcal} / \mathrm{kg})$. To assay for soluble condensed tannins (SCT), the aqueous acetone leaf extract $(0.5 \mathrm{ml})$ was utilized by means of modified butanol-HCl reagent $(95: 5 \mathrm{v} / \mathrm{v})$ (Porter et al. 1986). The utilization of a spectrophotometer (T60 UV-Visible Spectrophotometer, PG Instruments) of absorbance was observed at $550 \mathrm{~nm}$ wavelength. The mineral content of calcium $(\mathrm{Ca})$, magnesium $(\mathrm{Mg})$, potassium $(\mathrm{K})$, sodium $(\mathrm{Na})$, iron $(\mathrm{Fe})$, zinc $(\mathrm{Zn})$, manganese $(\mathrm{Mn})$ and copper $(\mathrm{Cu})$ of L. leucocephala leaves was determined, using the atomic ICP spectrophotometer (AAS-Buck 205) according to the procedures provide by the Agri-Laboratory Association of Southern Africa (AgriLASA 1998).

\section{Nutrient digestibility}

For the digestibility trial, twelve Potchefstroom Koekoek and twelve Black Australorp breeds (twenty-four chickens) were used. A factorial experiment in a completely randomized design (SAS 2010) was used for the trial (two breeds $\times$ four diets) with each treatment replicated three times. At the end of the experiment, the chickens were 90 days old when apparent nutrient digestibility was measured. Chickens (3 per treatment) were randomly and individually placed in metabolic pens for estimation of apparent digestibility. A 5-day acclimatization period was allowed prior to a 7-day collection period. Each replicate for collected excreta was kept at $-15{ }^{\circ} \mathrm{C}$ pending proximate analyses throughout the collection period to preserve the nutrient available on faeces (Gollcher et al. 2010). The feed offered and leftovers were weighed. The apparent digestibility values of dry matter (DM), crude protein (CP), neutral detergent fibre (NDF) and acid detergent fibre (ADF) were measured according to Mcdonald et al. (2005):

Apparent digestilbilty $=\frac{\text { Nutrient intake }- \text { faecal nutrient }}{\text { Nutrient intake }} \times 100$ 


\section{Mimosine content}

A mixture of sodium nitrates and SAM solutions were added together and permissible to stand for $20 \mathrm{~min}$ for diazotization of SAM to occur (DSAM solution). A corresponding liquor of mimosine working standard solutions was also prepared. Test tube series of $0.005-15 \mathrm{~g} / \mathrm{ml}$ were transferred in duplicate and volume. Each tube was adjusted to $0.5 \mathrm{M} \mathrm{HCl}$. The control tubes were added with $0.5 \mathrm{M} \mathrm{HCl}$. A $1 \mathrm{ml}$ solution of sodium carbonate and $2 \mathrm{ml}$ solution of DZSAM were added. A total of $1 \mathrm{ml}$ of NEDA solution was added together, permissible to stand in a room temperature for $10 \mathrm{~min}$, and then adjusted volume to $6 \mathrm{ml}$ water level. A mixture of solution and colour was developed for $10 \mathrm{~min}$ at room temperature. The absorbance values were recorded at $539 \mathrm{~nm}$, and the calibration curve was erected by plotting the absorbance (absorbance, Ao), when absence of mimosine was added absorbance.

\section{Statistical analysis}

The chemical composition data of the leaves was analysed using one-way ANOVA (SAS 2010). The general linear model employed was:

$Y_{i j k}=\mu+S_{i}+E_{i j}$

where $Y_{i j k}$ is the observation of the dependent variable $i j k$ (chemical composition of the leaves), $\mu$ is the fixed effect of population mean for the variable, $S_{i}$ is the stage of growth of leaves and $E_{i j}$ is the random error associated with observation $i j$ assumed to be normally and independently distributed.
A two-way ANOVA was used to analyse data on the effect of chicken breed, diet and chicken breed $\times$ diet interaction on apparent digestibility data. The general linear model (GLM) procedures of SAS (2010) software were employed in this statistical analysis. The linear model employed was:

$Y_{i j k}=\mu+S_{i}+D_{j}+(S \times D)_{i j}+E_{i j k}$

where $Y_{i j k}=$ observation of the dependent variable $i j k$, $\mu=$ fixed effect of population mean for the variable, $S_{i}=$ effect of chicken breed $(i=2$; Potchefstroom Koekoek and Black Australorp), $D_{j}=$ effect of diet ( $j=4$; LLM0, LLM2.5, LLM5.0 and LLM7.5), $(S \times D)_{i j}=$ effect of interaction between strain at level $i$ and diet at level $j$ and $E_{i j k}=$ random error associated with observation $i j k$ assumed to be normally and independently distributed.

The significance level was set at $P<0.05$. If the significant variation was detected on chemical components, multiple comparisons of treatment means were carried out using the probability of difference (pdiff) option of the general linear model (GLM) procedures of SAS.

\section{Results}

\section{Tender and mature leaves}

The nutritional composition of L. leucocephala leaf meal collected at two maturity stages is presented in Table 2 . The obtained results revealed that tender and mature leaves had significantly $(P<0.05)$ similar DM, ash, ADF, NDF, ADL, ether extract, cellulose and hemicellulose. However, there
Table 2 Nutrient composition $(\mathrm{g} / \mathrm{kg}$, unless otherwise stated) and mimosine content of tender and mature leaves of Leucaena leucocephala leaves

\begin{tabular}{lllll}
\hline Parameters & Tender leaves & Mature leaves & SE & $P$ value \\
\hline Dry matter (g/kg) & 923.68 & 920.26 & 1.443 & 0.168 \\
Ash (g/kg DM) & 84.99 & 87.42 & 2.637 & 0.549 \\
Acid detergent fibre (g/kg DM) & 178.81 & 179.70 & 3.308 & 0.859 \\
Neutral detergent fibre (g/kg DM) & 234.36 & 254.44 & 12.391 & 0.392 \\
Acid detergent lignin (g/kg DM) & 192.41 & 196.20 & 4.335 & 0.569 \\
Crude protein g/kg DM & $275.10^{\mathrm{a}}$ & $255.37^{\mathrm{b}}$ & 1.278 & 0.001 \\
Ether extract (g/kg DM) & $40.46^{\mathrm{a}}$ & $23.60^{\mathrm{b}}$ & 8.212 & 0.001 \\
Cellulose (g/kg DM) & 172.40 & 172.90 & 3.332 & 0.917 \\
Hemicellulose (g/kg DM) & 78.30 & 58.26 & 11.426 & 0.335 \\
Condensed tannins (g/kg DM) & $24.68^{\mathrm{b}}$ & $35.55^{\mathrm{a}}$ & 0.564 & 0.003 \\
Dry matter digestibility (\% DM) & $73.91^{\mathrm{a}}$ & $73.59^{\mathrm{b}}$ & 0.018 & 0.008 \\
Total digestible nutrients (\% DM) & $67.91^{\mathrm{a}}$ & $67.61^{\mathrm{b}}$ & 0.018 & 0.008 \\
Digestible energy (Mcal/kg) & $3.43^{\mathrm{a}}$ & $3.42^{\mathrm{b}}$ & 0.000 & 0.008 \\
Metabolisable energy (Mcal/kg) & $2.82^{\mathrm{a}}$ & $2.81^{\mathrm{b}}$ & 0.000 & 0.008 \\
Mimosine (g/kgDM) & $46.1^{\mathrm{a}}$ & $25.5^{\mathrm{b}}$ & 0.577 & 0.003 \\
\hline
\end{tabular}

${ }^{\mathrm{a}, \mathrm{b}}$ Means within rows with different superscripts differ significantly $(P<0.05)$. $S E$, standard error; $P$, probability 
Table 3 Mineral content of tender and mature Leucaena leucocephala leaves

\begin{tabular}{lllll}
\hline Parameters & Tender leaves & Mature leaves & SE & $P$ value \\
\hline Calcium (\%) & $1.87^{\mathrm{a}}$ & $1.76^{\mathrm{b}}$ & 0.041 & 0.001 \\
Magnesium (\%) & $3.20^{\mathrm{a}}$ & $2.65^{\mathrm{b}}$ & 0.058 & 0.002 \\
Potassium (\%) & $7.92^{\mathrm{a}}$ & $4.12^{\mathrm{b}}$ & 0.057 & 0.002 \\
Sodium (\%) & $2.76^{\mathrm{a}}$ & $2.53^{\mathrm{b}}$ & 0.056 & 0.001 \\
Iron (mg/100 g) & $312.60^{\mathrm{b}}$ & $347.76^{\mathrm{a}}$ & 4.103 & 0.002 \\
Zinc (mg/100 g) & $250.94^{\mathrm{b}}$ & $398.22^{\mathrm{a}}$ & 0.577 & 0.002 \\
Manganese & 330.10 & 342.56 & 4.103 & 0.372 \\
$\quad(\mathrm{mg} / 100 \mathrm{~g})$ & & & & \\
Copper $(\mathrm{g} / 100 \mathrm{~g})$ & $394.07^{\mathrm{b}}$ & $484.79^{\mathrm{a}}$ & 4.082 & 0.001 \\
\hline
\end{tabular}

a,b Means within rows with different superscripts differ significantly $(P<0.05) . S E$, standard error; $P$, probability

were significantly higher $(P<0.05)$ concentrations of crude protein, mimosine and chemical estimates predicted on tender leaves when compared to mature leaves.

In Table 3, tender leaf concentrations were significantly higher $(P<0.05)$ in calcium $(1.87 \mathrm{~g} / \mathrm{kg} \mathrm{DM})$, magnesium (3.20 / kg DM), potassium $(7.92 \mathrm{~g} / \mathrm{kg} \mathrm{DM})$ and sodium $(2.76 \mathrm{~g} / \mathrm{kg} \mathrm{DM})$. Iron $(347.76 \mathrm{mg} / 100 \mathrm{~g})$ and zinc $(398.22 \mathrm{mg} / 100 \mathrm{~g})$ contents for mature leaves were higher compared to tender leaves. There were no significant differences detected in manganese concentration in leaf materials.

Diet $\times$ breed interaction significantly affected apparent digestibility of ADF and NDF (Figs. 1 and 2) and non-significantly on apparent digestibility of dry matter (DM) and crude protein $(\mathrm{CP})$. The Potchefstroom Koekoek revealed the lowest $(P<0.05)$ ADF digestibility $(27.23 \%)$ in LLM5.0 and the highest ADF digestibility in other diets (Fig. 1). The BA had the lowest ADF digestibility (27.37\%) across all incremental levels except in LLM5.0 (Fig. 1). The BA breed showed the highest $(P<0.05)$ NDF digestibility in all diets with the PK breed being the lowest (Fig. 2).

There was higher feed intake in chickens fed 7.5\%LLM as compared to chickens fed the control diet (Table 4). The NDF digestibility was similar $(P>0.05)$ for the diets of LLM2.5 and LLM7.5. The digestibility of CP decreased $(P<0.05)$ with increased dietary LLM which was evident
Fig. 1 Effect of dietary Leucaena leucocephala leaves meal supplementation level (\%) on apparent digestibility of acid detergent fibre (ADF) in 12-week-old Potchefstroom Koekoek (PK) and Black Australorp (BA) chicken breeds
Fig. 2 Effect of dietary Leucaena leucocephala leaves meal supplementation level (\%) on apparent digestibility of neutral detergent fibre (NDF) in 12-week-old Potchefstroom Koekoek (PK) and Black Australorp (BA) chicken breeds
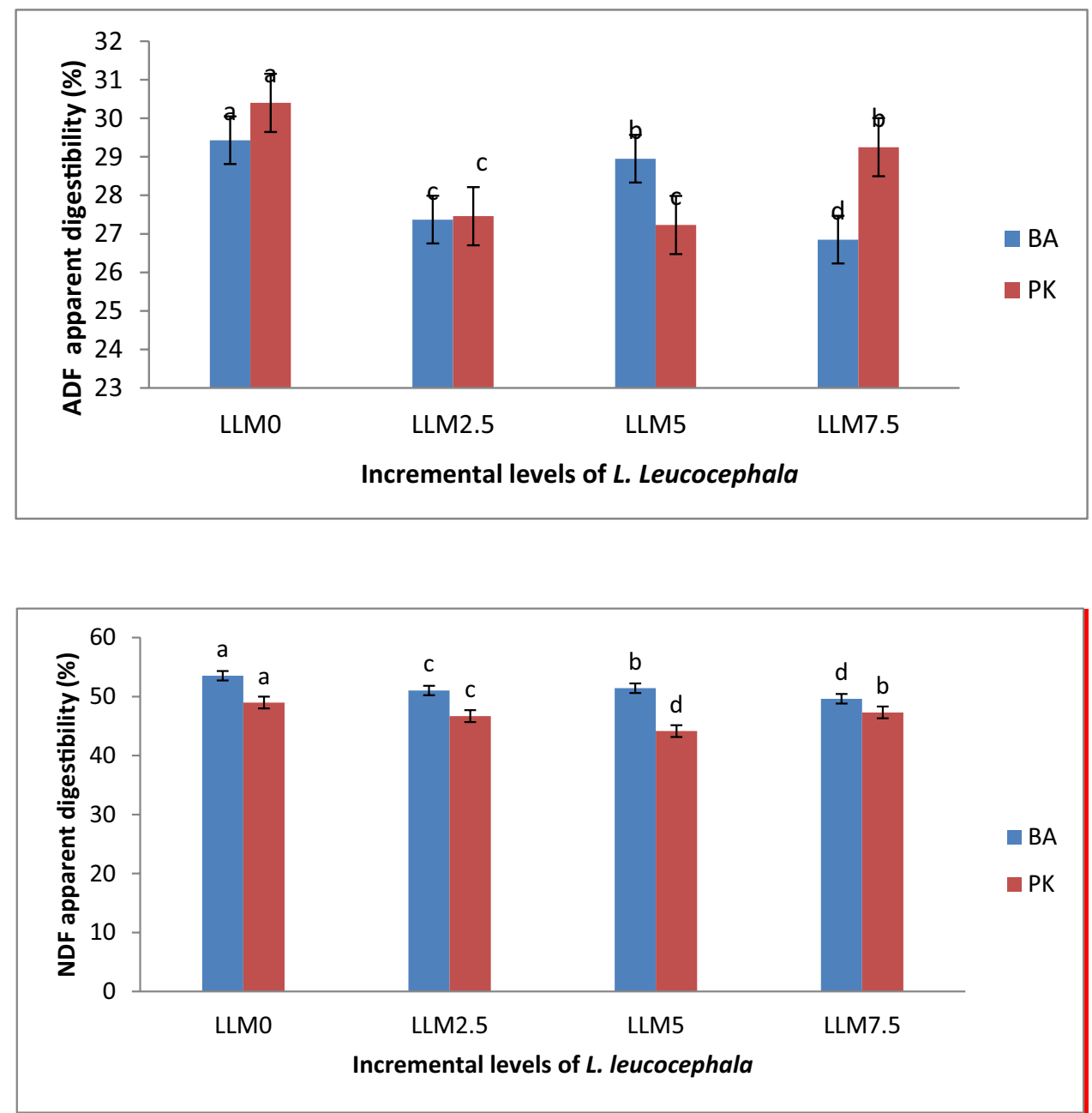
Table 4 Effects of Leucaena leucocephala leaf meal supplementation on feed intake (g) and apparent digestibility (\%) of dry matter (DM), acid detergent fibre (ADF), neutral detergent fibre (NDF) and crude protein $(\mathrm{CP})$

\begin{tabular}{lllllll}
\hline Diet & \multicolumn{7}{l}{} \\
\hline Parameters & LLM0 & LLM2.5 & LLM5.0 & LLM7.5 & $P$ value & SE \\
\hline Feed intake (g) & $1112.50^{\mathrm{b}}$ & $1123.00^{\mathrm{b}}$ & $1140.83^{\mathrm{ab}}$ & $1198.39^{\mathrm{a}}$ & 0.022 & 20.43 \\
DM\% & 89.00 & 88.53 & 88.84 & 88.58 & 0.99 & 1.58 \\
ADF\% & $29.92^{\mathrm{a}}$ & $27.42^{\mathrm{d}}$ & $28.09^{\mathrm{b}}$ & $28.05^{\mathrm{c}}$ & 0.001 & 0.29 \\
NDF\% & $51.26^{\mathrm{a}}$ & $48.86^{\mathrm{b}}$ & $47.79^{\mathrm{c}}$ & $48.47^{\mathrm{b}}$ & 0.001 & 0.35 \\
CP\% & $71.00^{\mathrm{a}}$ & $53.19^{\mathrm{b}}$ & $47.47^{\mathrm{c}}$ & $38.81^{\mathrm{d}}$ & 0.001 & 0.17 \\
\hline
\end{tabular}

${ }^{\text {abcd } M e a n s ~ w i t h i n ~ r o w s ~ w i t h ~ d i f f e r e n t ~ s u p e r s c r i p t s ~ a r e ~ s i g n i f i c a n t l y ~ d i f f e r e n t ~}(P<0.05)$. SE, standard error; $L L M O$, control diet containing $0 \%$ of Leucaena leaf meal; LLM2.5, diet containing $2.5 \%$ of Leucaena leaf meal; LLM5.0, diet containing 5\% of Leucaena leaf meal; LLM7.5, diet containing $7.5 \%$ Leucaena leaf meal; $D M$, dry matter $\% ; A D F$, acid detergent fibre $\% ; N D F$, neutral detergent fibre $\% ; C P$, crude protein $\%$ with diet LLM7.5. However, the digestibility of ADF, NDF and $\mathrm{CP}$ was reduced $(P<0.05)$ with the inclusion of LLM.

\section{Discussion}

\section{Nutritional composition}

The maturity stage and the growing conditions of plant have an effect on nutritional value of forage (Msiza et al. 2021; Sebola et al. 2019). The results of the chemical composition of L. leucocephala are in agreement with various reports (Dhär et al. 2007; Mohamed et al. 2014; Reyes and Fermin 2003; Leketa et al. 2019; Ayssiwede et al. 2010). The crude protein content in this study was higher than $23 \% \mathrm{CP}$ of DM reported by Onibi et al. (2008), but lower than the range of 28-29\% CP of DM reported by Munguti et al. (2006). These variations in CP contents might be due to differences in agro-climatic conditions and ages of trees and possibly due to different stages of maturity (Ayssiwede et al. 2010). The results imply that tender leaves contain high protein content which will meet the nutrient requirements of indigenous laying hens better than the mature leaves.

Tender leaves had higher protein content and less fibre, thus have greater potential as a feed additive for high poultry performance due to limited ability of chickens to digest fibre-rich diets (Sebola et al. 2019). At both stages of maturity, the average amount of ether extract is estimated on account that leaves are not a principal source of lipids.

The older plants had higher fibre while there was less CP and digestible dry matter. This has been confirmed by the results of Hassen et al. (2007) for the effect of season on nutritive value of five Indigofera species (I. amorphoides, Indigofera arrecta, I. brevicalyx, I. castata and Indigofera cryptantha). The neutral detergent fibre content of both mature and tender leaves in the current study was less than $35 \%$ which will make the diet more digestible (Norton 1994). Higher calcium, magnesium and potassium concentrations were obtained in tender leaves compared to matured leaves. For normal growth, muscle activity and skeletal development in poultry, calcium is required. In laying hens, calcium is also vital for egg shell formation. Both tender and mature leaves can be used in indigenous laying hens' diets as they will add calcium for optimal growth, bone strength and development. The Ca concentration recorded in this study for air-dried Leucaena leaves was similar to the results reported by Leketa et al. (2019). Iron was higher in matured leaves, which is an essential factor of myoglobin and haemoglobin for oxygen transportation and cellular development and division (Kozat 2007). The tender leaves had higher concentration of magnesium than mature leaves. $\mathrm{Mg}$ is responsible for chemical reactions in the body and intestinal absorption of Zn (Muhammad et al. 2011). The mineral concentration of Leucaena leaves will meet the nutrient requirement for the production for growing chickens. Tannins are being efficiently utilized and included in a components diet of poultry for enhancement of animal overall performance and also to control diseases (Suleyman 2017). Dietary tannins are said to reduce feed efficiency and growth rate in chicks (Dei et al. 2007) when fed in large quantities. Generally, the composition of phenolic compounds can be affected by stage of maturity, post-harvest handling, processing and storage (Sreelatha and Padma 2009). Tannin content was higher in matured leaves, which is possible to hinder performance development in chickens as compared to the tender leaves. In poultry, studies have shown the anti-nutritional tannin effects in chicken feeding; they induce productive performances as a result of reducing feed intake and organic matter digestibility, especially the protein component (Garcia et al. 2004; Longstaff and McNab 2007).

The levels of mimosine measured in this study for the leaves were within the range reported by Longstaff and $\mathrm{McNab}$ (2007). The mimosine value was high in the tender leaves as compared to the mature leaves. A similar pattern of a decline of mimosine concentration with extended growth for the leaves was observed by Tangendjaja et al. (1986) for Leucaena leaves. The authors observed high levels of mimosine (40-50 g/kg dry weight) in young leaves, but the 
level fell rapidly within 5 weeks to $10 \mathrm{~g} / \mathrm{kg} \mathrm{DM}$, and at week 10 , the level then gradually decreased to about $2 \mathrm{~g} / \mathrm{kg} \mathrm{DM}$.

However, the levels of mimosine measured in this study for the leaves were relatively low as compared with the results observed by other authors (Tangendjaja et al. 1986; Adeneye 1991). This might be attributed by the use of the dried Leucaena forage in this study.

\section{Nutrient digestibility}

Factors that affect digestibility amongst others are enzymes, hydrochloric acid and bile by endogenous secretions. For effective utilization of feed, it must be digested and absorbed by the chickens (Ndelekwute et al. 2018). The possible effect of anti-nutritional factors, for example, mimosine and tannins present in the L. leucocephala plant fed to Black Australorp and Potchefstroom Koekoek chicken breeds, may have caused the apparent changes in digestibility (Safwat et al. 2015; Simon 2012). Different chicken breeds exhibited different apparent digestibility coefficients (Sebola et al. 2018). This could be credited to hereditary contrasts in the ability of each breed to utilize high fibre feeds. The results showed that BA breeds have a better tolerance to fibre and anti-nutritional factors in the diet when LLM was included, even up to $7.5 \%$. The current results revealed no significant dietary treatment on DM digestibility suggesting that chicken breeds were not affected by the fibre and anti-nutritional factors present in the LLM. The results are in agreement with Ayssiwede et al. (2010), who reported that diet with or without LLM fed on hens had no significance effect on utilization value of DM digestibility. In contrast, AbouElezz et al. (2012) reported that feeding Rhode Island Red hens 0, 5, 10 and 15\% LLM had no effect on NDF digestibility. de Oliveira et al. (2014) reported that DM digestibility decreased by adding 10\% LLM in the diets and enhance the excretion of DM in faeces by laying hens fed diet with a higher proportion of fibre. The author further explained that the excretion of DM increases because the fibrous fraction is digested in the digestive tract. A decrease in the protein and the fibrous fraction in the diet of indigenous chickens had no significant effect on DM (Arruda et al. 2010). The dry matter digestibility values obtained in the present study were similar to those reported by Abou-Elezz et al. (2012).

Kakengi et al. (2007) reported that including high levels of 10 and $15 \%$ of LLM and MOLM in the diets of laying hens resulted in lower CP digestibility. Iheukwumere et al. (2008) reported similar results with broilers where the digestibility values of DM, CP and CF were lower in 10 and $15 \%$ cassava leaf supplemental levels than in the control. Safwat et al. (2015) and Simon (2012) reported similar lower apparent digestibility value of crude protein in indigenous laying hens and in rabbits fed LLM. These reports are in agreement with the Nieves et al. (2002) who reported lower DM and CP digestibility values in LLM diets when compared to the control diets. Decrease in feed intake by anti-nutritional compounds in the diet caused decreased digestibility through the ability to bond with proteins and other nutrients (AL-Mamary et al. 2001; Safwat et al. 2015).

The lower crude protein digestibility of the LLM diet agreed with Nieves et al. (2002), who reported a low crude protein digestibility of LLM fed to rabbits when compared to the control diet. Other authors cited that the indigestible protein fraction in the leaf meal may be found in fibrous components (Jensen et al. 1995). The current findings showed that breed and diet interaction did not affect DM and CP digestibility of the selected indigenous laying hens. Apparent digestibility of crude protein in the diet containing $L$ leucocephala leaves was higher than that of Cassava leaves (Ayssiwede et al. 2010; Iheukwumere et al. 2008). Commonly, fibre ratios (soluble fibre vs. insoluble fibre) play an important role on digestion rate and the absorption of nutrients (Sebola et al. 2018). Higher fibre digestibility in the control diet indicates that soybean meal fibre is highly digestible compared to LLM fibre. The observed increment of dietary fibre digestibility with increasing the inclusion level of leaf meals in the diets could possibly be due to the unbalance of dietary fibre fractions in terms of the proportions of cellulose, hemicellulose and lignin from the leaf meals and hence deterioration of fibre digestive capacity.

\section{Conclusion}

Significant variation was obtained in the chemical composition of tender and mature L. leucocephala leaves. The study concluded that tender leaves of Leucaena had a higher crude protein, mineral and mimosine concentration but lower fibre content than mature leaves. The data on digestibility of this alternative protein source shows that incorporation of LLM in the diets of laying hens did not negatively affect the digestibility of dry matter. The data obtained from this study on digestibility coefficients of dietary nutrients states that the inclusion of LLM in the diets of Black Australorp and Potchefstroom Koekoek chicken breeds could be recommended between 5 and $7.5 \%$ of the diet. However, there is a need to assess the effect of incorporating LLM in the diet for feed efficiency and egg production and egg size on hen.

Acknowledgements The first author appreciates the financial support of the Department of Agriculture, Rural Development, Land and Environmental Affairs, Mpumalanga province, South Africa.

Author contribution Conceptualization, MWT, H.K.M, N.A.S and K.E.R; Data curation, MWT; Formal analysis, M.W.T, H.K.M, N.A.S and K.E.R; Methodology, MWT, H.K.M, N.A.S and K.E.R; Supervision, H.K.M and N.A.S; Validation, H.K.M, N.A.S; Writing - original draft, MWT, H.K.M and K.E.R; Writing - review and editing, H.K.M, 
N.A.S and K.E.R. The authors have read and agreed for the published version of the manuscript.

Data availability All data analysed during the current study are available from the corresponding author on request.

\section{Declarations}

Ethics approval All applicable guidelines for the care and use of animals were followed, and the study was approved by North West University Animal Research Ethic Committee with a reference number NWU-00242-18-A5.

Conflict of interest The authors declare no competing interests.

Open Access This article is licensed under a Creative Commons Attribution 4.0 International License, which permits use, sharing, adaptation, distribution and reproduction in any medium or format, as long as you give appropriate credit to the original author(s) and the source, provide a link to the Creative Commons licence, and indicate if changes were made. The images or other third party material in this article are included in the article's Creative Commons licence, unless indicated otherwise in a credit line to the material. If material is not included in the article's Creative Commons licence and your intended use is not permitted by statutory regulation or exceeds the permitted use, you will need to obtain permission directly from the copyright holder. To view a copy of this licence, visit http://creativecommons.org/licenses/by/4.0/.

\section{References}

Abou-Elezz, F.M.K., Sarmeo-Franco, L., Santos-Ricalde, R. and Solorie-Sanchez, F., 2012. Apparent digestibility of Rhode Island Red hens' diets containing Leucaena leucocephala and Moringa oleifera leaf meals. Tropical and Subtropical Agroecosystems, 15 (2), 199-206.

Adeneye, J.A., 1991. Mimosine content in various fractions of $\mathrm{Leu}$ caena leucocephala grown in Western Nigeria. Animal Feed Science and Technology, 33, 349-353.

Agri Laboratory Association of Southern Africa. Feed and plant analysis methods. AgriLASA, Pretoria. 1998.

Al-Mamary, M., Molham, A.H., Abdulwali, A.A. and Al-Obeidi, A., 2001. In vivo effects of dietary sorghum tannins on rabbit digestive enzymes and mineral absorption. Nutrition Research, 21(10), 1393-1401.

AOAC. 2005. Official Methods of Analysis, 17th edition, A.O.A.C., Washington D.C.

Arruda, A.M.V., de Fernandes, R.T.V., Oliveira, J.F., de Filgueira, T.M.B., Fernandes, D.R. and Galvao, R.J.D., 2010. Energetic value of forage hays from Brazilian semiarid to Isa Label chickens. Acta Veterinaria Brasilica, 4, 105-112.

Ayssiwede, S.B., Dieng, A., Chrysostome, C., Ossebi, W., Hornick J.L. and Missohou, A., 2010. Digestibility and metabolic utilization and nutritional value of Leucaena leucocephala (Lam) leaves meal incorporated in the diets of indigenous Senegal chickens. International Journal Poultry Science, 67.

Ayssiwede, S.B., Chrysostome, C.A.A.M., Zanmenou, J.C., Dieng, A., Houinato, M.R., Dahouda, M., Akpo, Y., Hornick, J.L. and Missohou, A., 2011. Growth performances, carcass and organs characteristics and economics results of growing indigenous Senegal chickens fed diets containing various levels of Leucaena leucocephala (Lam.) leaves meal. International Journal Poultry Science, 10, 734-749.

Bath, D.L. and Marble, V.L., 1989. Testing alfalfa for its feeding value. Leaflet. 21437. WREP 109. Division of Agricultural Natural Resources. Oakland, California: University California.

Buxton, D.R., 1996. Quality related characteristics of forages as influenced by plant environment and agronomic factors. Animal Feed Science and Technology, 59, 37-49.

Dei, H.K., Rose, S.P. and Mackenzie, A.M., 2007. Shea nut (Vitellaria paradoxa) meal as a feed ingredient for poultry. World's Poultry Science Journal 63(4), 611-624.

de Oliveira, A.N., Freitas, E.R.F., Cruz, C.E.B.C., Filgueira, T.M.B., Nascimento, G. A.J. and Lima, R.C., 2014. Inclusion of Leucaena leaf hay in the diet of laying hens during the growing phase. Departamento de Zootecnia, Centro de Ciências Agrárias, Universidade Federal do Ceará, Rua Campus do Pici, s/n, Bloco. 810.

Dhär, M., Chowdhury, S.D., Ali, M.A., Khan, M.J. and Pramanik, M.A.H., 2007. Responses of semi-scavenging F1 crossbred (Rhode Island Red male $x$ Fayoumi female) grower and pre-layer chickens to diet of different nutrient density formulated with locally available Feed ingredients. Journal of Poultry Science, $44,42-51$

Dyubele, N.L., Muchenje, V., Nkukwana, T.T. and Chimonyo, M., 2010. Consumer sensory characteristics of broiler and indigenous chicken meat: A South African example. Food Quality and Preference, 21(7), 815-819.

FAO, 2014. Family poultry development-issues, opportunities, and constraints; Animal Production and Health Working Paper No. 12, Food and Agriculture Organization of the United Nations: Rome, Italy.

Fonnesbeck, P.V., Clark, D.H., Garret, W.N. and Speth, C.F., 1984. Predicting energy utilization from alfalfa hay from the Western Region. In: Proceedings of the 2002 Cornell Nutrition Conference for Feed Manufacture, East Syracuse, New York. Ithaca, New York: Cornell University.

Fourie, C. and Grobbelaar, J.A.N. 2003. Indigenous poultry breeds, 20-21. Krugersdorp, Germany, Wing Nut Publications.

Garcia, G.W., Ferguson, T.U., Neckles, F.A. and Archibald, K.A.E., 1996. The nutritive value and forage productivity of Leucaena leucocephala. Animal Feed Science and Technology, 60(1-2), 29-41.

Garcia, R.G., Mendes, A.A., Sartori, J.R., de Lima Almeida Paz, I.C., Takahashi, S.E., Pelícia, K., Komiyama, C.M. and Quinteiro, R.R., 2004. Digestibility of feeds containing sorghum, with and without tannin, for broiler chickens submitted to three room temperatures. Brazilian Journal of Poultry Science, 6, 55-60.

Gollcher, A.M.R., José Augusto de Freitas Lima, Elias Tadeu Fialho, Paulo Borges Rodrigues, P.R. and Renato Ribeiro de Lima, R.R., 2010. Nutritional value of high and low tannin high-moisture sorghum grain silage in horses. Revista Brasileira de Zootecnia.39 (6), 1246-1251.

Grobbelaar J.A.N., 2008. Egg production potentials of four indigenous chicken breeds in South Africa. Pretoria, Tshwane University of Technology. (M.Tech. thesis).

Grobbelaar, J.A.N., Sutherland, B. and Molalakgotla, N.M., 2010. Egg production potentials of certain indigenous chicken breeds from South Africa. Animal Genetic Research. 46, 25-32.

Hassen, A., Rethman, N.F.G, van Nierkerk, W.A. and Tjelele, T.j., 2007. Influence of season/year and species on chemical composition and in vitro digestibility of five Indigofera accessions. Animal Feed Science and Technology 136, 312-322.

Houndonougbo, M.F., Chrysostome, C.A.A.M. and Houndonougbo, V.P., 2012. Performances de ponte et qualité des oeufs des poules pondeuses ISA Brown alimentées avec des rations à base de feuilles séchées de manioc (Manihot esculenta, Crantz). International Journal of Biological Chemical Science 6, 1950 -1959. 
Iheukwumere, F.C., Ndubuisi, E., Mazi, E.A. and Onyekwere, M.U., 2008. Performance, nutrient utilization and organ characteristics of broilers fed cassava leaf meal (Manihot, Esculenta). Pakistan Journal of Nutrition, 7, 13.

Jensen, M.T., Cox, R.P. and Jensen, B.B., 1995. Microbial production of skatole in the hind gut of pigs given different diets and its relation to skatole deposition in back fat. Animal Science, 61, 293-304.

Kakengi, A.M.V., Kaijage, J.T., Sarwatt, S.V., Mutayoba, S.K., Shem, M.N. and Fajihara, T., 2007. Effect of Moringa Oleifera leaf meal as a substitute for sunflower seed meal on performance of laying hens in Tanzania. Livestock Research for Rural Development, 19, 8.

Khalil, J.K., Sawaya, W.N. and Hyder, S.Z., 1986. Nutrient composition of Atriplex leaves grown in Saudi Arabia. Journal of Range Management, 39, 104-107.

Kozat, S., 2007. Serum T3 and T4 concentrations in lambs with nutritional myodegeneration. Journal of Veterinary International Medication, 21, 1135-1137.

Leketa, K., Donkin, E.F., Hassen, A. and Akanmu, A.M., 2019. Effect of Leucaena leucocephala, as a protein source in a total mixed ration, on milk yield and composition of Saanen milk goats, Journal of Animal Science, 49 (2).

Longstaff, M. A. and McNab, J. M. 2007. The effect of concentration of tannin-rich bean hulls (Vicia faba L.) on activities of lipase (EC 3.1.1.3) and $\alpha$-amylase (EC 3.2.1.1) in digesta and pancreas and on the digestion of lipid and starch by young chicks. Brazilian Journal of Nutrition 66, 139.

Mbajiorgu, C.A., Ng'ambi, J.W. and Norris, D., 2011. Effect of varying dietary energy to protein ratio level on growth and productivity of indigenous Venda chickens. Asian Journal of Animal Veterinary 6, 344-352.

Mcdonald, P., Edwards, R.A., Greenhalgh, J.F.D. and Morgan, C.A., 2005. Animal nutrition, 4th edition. Longman Scientific and Technical publishers, New York, 200-216.

Mngonyama, M.B.A., 2012. Morphometric characteristics and consumer acceptability of meat from Potchefstroom Koekoek, Black Australorp, Venda and Ovambo chickens. University of KwaZuluNatal Pietermaritzburg South Africa. (MSc. Thesis).

Mohamed, Z.Z., Mohamed, A.Z., Fasihuddin, B.A., Wei-Seng H. and Shek, L.P., 2014. Comparison of Mimosine Content and nutritive values of Neolamarckia cadamba and Leucaena leucocephala with Medicago sativa as forage quality Index. International Journal of Science Technology Research, 3, (8), 146-150.

Msiza, N.H., Ravhuhali, K.E., Mokoboki, H.K., Mavengahama, S. and Motsei, L.E., 2021. Ranking Species for Veld Restoration in SemiArid Regions Using Agronomic, Morphological and Chemical Parameters of Selected Grass Species at Different Developmental Stages under Controlled Environment. Agronomy 11, (1), 52. https://doi.org/10.3390/agronomy 1101005 .

Muchadeyi, F.C., Wollny, C.B.A., Eding, H., Weigend, S., Makuza, S.M. and Simianer, H., 2007. Variation in village chicken production systems among agro-ecological zones of Zimbabwe. Tropical Animal Health and Production, 39(6), 453-461.

Muhammad, A., Dangoggo, S.M., Tsafe A.I., Itodo, A.U. and Atiku, F.A., 2011. Proximate, minerals and anti-nutritional factors of Gardenia aqualla (Gauden dutse) fruit pulp. Pakistan Journal of Nutrition, 6, 577-581.

Munguti, J.M., Liti, D.M., Waidbacher, H., Straif, M. and Zollitsch, W., 2006. Proximate composition of selected potential feedstuffs for Nile tilapia (Oreochromis niloticus Linnaeus) production in Kenya, Australian Journal of Agricultural Research. 57, 131-141.

Ndelekwute, E.K., Assam, E.D. and Assam, E.M., 2018. Apparent nutrient digestibility, gut $\mathrm{pH}$ and digesta viscosity of broiler chickens fed acidified water. MOJ Anatomy \& Physiology. 5 (4), 250-253.
Nieves, D., Silva, B., Teran, O. and Gonzalez, C., 2002. Increasing levels of Leucaena leucocephala in fattening rabbit's diets. Revista Cientifica, Facultad de Ciencias Veterinarias, Universidad del Zulia, 12 (Supplemento 2), 419-421.

Norton, B.W., 1994. The nutritive value of tree legumes. In: Gutteridge, R.C., Shelton, H.M. Eds, Forage tree legumes in tropical Agriculture. CAB International, 192-201.

Okitoi, L.O., Udo, H.M.J., Mukisira, E.A., de Jong, R. and Kwakkel, R.P., 2006. Evaluation of low - Input improved productivity of indigenous chickens in Western Kenya. Agricultural Tropical Subtropical, 39, 178-181.

Olugbemi, T.S., Mutayoba, S.K. and Lekule, F.P., 2010. Effect of Moringa (Moringa oleifera) inclusion in cassava based diets fed to broiler chickens. International Journal of Poultry Science, 9(4), 363-367.

Onibi, G.E., Folorunso, O.R. and Elumelu, C. (2008). Assessment of partial equi-protein replacement of soyabean meal with cassava and Leucaena leaf meals in the diets of broiler chicken finishers. International Journal of Poultry Science, 7 (4), 408-413.

Porter, L.J., Hirstich, L.N. and Chan, B.G., 1986. The conversion of procyanidins and prodelphinidins to cyanidin and delphinidin. Phytochemistry, 25, 223-230.

Ramsey, K., Harris, L. and Kotze, A., 2001. Landrace breeds. South Africa's indigenous and locally developed farm animals. Pretoria, Farm Animal Conservation Trust. South Africa.

Reyes, O.S. and Fermin, A.C., 2003. Terrestrial leaf meals or freshwater aquatic fern as potential feed ingredients for farmed abalone Haliotis asinina (Linnaeus 1758). Aquaculture Research, 34, 593-599.

Safwat, A.M., Sarmiento-Franco, L., Santos-Ricalde, R.H. and Nieves, D., 2014. Determination of tropical forage preferences using two offering methods in rabbits. Asian- Australian Journal of Animal Science, 27, 524-529.

Safwat, A.M., Sarmiento-Franco, L., Santos-Ricalde, R.H., Nieves, D. and Sandoval-Castro, C.A., 2015. Estimating apparent nutrient digestibility of diets containing Leucaena leucocephala or Moringa oleifera leaf meals for growing rabbits by two methods. Asian-Australian Journal of Animal Science, 28, 1155.

Sastry, M.S. and Singh, R., 2008. Toxic effects of subabul (Leucaena leucocephala) on thyroid and reproduction of female goats. Indian Journal of Animal Science, 78 (3), 251-253.

SAS, 2010. Statistical Analysis System user guide: Statistics. Version 9.3. SAS Institute, Cary, NC, USA.

Sebola, N.A., Mlambo, V., Mokoboki. H.K., Hugo, A. and Muchenje, V., 2018. Comparison of meat quality parameters in three chicken strains fed Moringa oleifera leaf meal-based diets. Journal of Applied Poultry Research, 27, 332-340.

Sebola, N.A., Mlambo, V. and Mokoboki, H.K., 2019. Chemical characterisation of Moringa oleifera (MO) leaves and the apparent digestibility of MO leaf meal-based diets offered to three chicken strains. Agroforest Systems, 93, 149-160.

Simon, M.K., 2012. Growth response and carcass characteristics of rabbit fed graded levels of Leucaena leucocephala diets. Continental Journal of Veterinary Sciences, 6, 10-13.

Small-farm-permiculture-and-sustainability-living.com., 2012. Types of chickens. Review of different breeds of chickens. http://www.small-farm-permaculture-and-sustainableliving. com/types of chickens.html.

Sonaiya, E.B., 2003. Producing local livestock-Improving rural livelihoods. Proceedings of 28th Annual Conference of the Nigerian Society for Animal Production, 28, 462.

Sreelatha, S. and Padma, P.R., 2009. Antioxidant activity and total phenolic content of Moringa oleifera leaves in two stages of maturity. Plant Foods for Human Nutrition, 64, 303-311. 
Suleyman, C., 2017. Tannins and their effects on poultry nutrition. International Conference Agriculture, forestry, food Science and Technology. Cappadocia, Turkey. 15-17 May 2017.

Tangendjaja, B., Lowry, A.B. and Wills, R.B.H., 1986. Changes in mimosine, phenol, protein and fibre content of Leucaena leucocephala leaf during growth and development. Australian Journal of Experimental Agriculture, 26, 315-317.

Tadelle, D. and Fasil, G., 2016. The Potchefstroom Koekoek Breed. African Chicken Genetic Gains. The International Livestock Research Institute: Nairobi, Kenya.

Tendonkeng, F.B., Boukila, A. and Beguidé Pamo, T.E., 2008 Essai de substitution du tourteau de soja par la farine de feuilles de Moringa oleifera dans la ration finition des poulets de chair.
Conférence Internationale sur le renforcement de la compétitivité en Aviculture Semi-industrielle en Afrique (CIASA); Dakar, Sénégal 5-9 mai.

Van Soest, P.J., Robertson, J.B. and Lewis, B.A., 1991. Methods for dietary fiber, neutral detergent fiber and non-starch polysaccharides in relation to animal nutrition. Journal of Dairy Science, 74, 3583-3597.

Publisher's note Springer Nature remains neutral with regard to jurisdictional claims in published maps and institutional affiliations. 